\title{
UJI STABILITAS PIGMEN EKSTRAK UBI BANGGAI (Dioscorea bulbifera var celebica BurkilI) PADA BERBAGAI VARIASI pH DAN LAMA PAPARAN SINAR MATAHARI
}

\author{
[Pigment Stability Assays of Banggai Cassava Extract (Dioscorea bulbifera var \\ celebica Burkill) at Various of Acidity and length of Sun Exposure] \\ Bryan Agung Rundubelo ${ }^{{ }^{\star}}$, Ahmad Ridhay ${ }^{1}$, Jaya Hardi ${ }^{1}$, Dwi Juli Puspitasari ${ }^{1}$ \\ 1) Jurusan Kimia, Fakultas MIPA, Universitas Tadulako, Palu \\ J. Soekarno Hatta Km.9, Kampus Bumi Tadulako Tondo Palu, Telp. 0451- 422611
}

*)Coresponding author: bryanagung823@ymail.com (082346862383)

Diterima 17 November 2018, Disetujui 17 Januari 2019

\begin{abstract}
The investigation about the potential of Banggai cassava (Dioscorea bulbifera var celebica Burkill) as a natural dye for foods and drinks in the term of $\mathrm{pH}$ stability and sun exposure has been done. The aim of this research was to determine the effect of $\mathrm{pH}$ and the sun exposure on the stability of cassava banggai during storage time. The applied storage time for the effect of $\mathrm{pH}$ and of sun exposure were 10 days and 5 hours, respectively. The result showed that the dye from banggai cassava extract was stable at $\mathrm{pH} 2$ during 10 days in storage with $37.38 \%$ of degradation level, while the effect of sun exposure on degradation level in the dark bottle was lower than in the light bottle. The degradation level in the dark bottle and in the light bottle were $36.91 \%$ and $41.96 \%$, respectively.
\end{abstract}

Keywords: Natural dye, the stability of banggai,cassava degradation

\begin{abstract}
ABSTRAK
Penelitian tentang potensi ubi banggai (Dioscorea bulbifera var celebica Burkill) sebagai pewarna alami makanan dan minuman yang ditinjau dari stabilitas $\mathrm{pH}$ dan paparan sinar matahari telah dilaksanakan. Tujuan dari penelitian ini adalah mengetahui kestabilan ekstrak ubi banggai terhadap pengaruh $\mathrm{pH}$ dan terhadap paparan sinar matahari selama masa penyimpanan. Waktu yang digunakan adalah 10 hari untuk penyimpanan terhadap pengaruh $\mathrm{pH}$ dan 5 jam untuk paparan sinar matahari. Hasil penelitian menunjukan zat warna ekstrak ubi banggai stabil pada $\mathrm{pH} 2$ setelah masa penyimpanan 10 hari dengan presentasi degradasi $37.38 \%$ sementara pengaruh paparan sinar matahari menghasilkan degradasi terendah pada botol gelap yaitu $36,91 \%$ dibandingkan dengan botol bening 41,96\%.
\end{abstract}

Kata Kunci : Zat warna, stabilitas ubi banggai, degradasi 


\section{LATAR BELAKANG}

Produk-produk makanan saat ini tidak lepas dari pewarna makanan. Pewarna yang sangat banyak beredar dipasaran dan digunakan oleh para pedagang makanan dan minuman adalah pewarna sintesis karena memiliki harga yang lebih murah. Dilain pihak jika hal ini terus berlangsung maka dikhawatirkan akan menyebabkan tingkat kesehatan masyarakat menurun mengingat dampak yang dapat ditimbulkan oleh pewarna sintesis. Jenie (1994) dalam Hidayah et al. (2014) menemukan bahwa pewarna sintetis pada makanan atau minuman memiliki resiko tinggi terhadap kesehatan karena bersifat karsinogenik. Lebih lengkap diuraikan oleh Depkes RI (2012), bahwa penggunaan pewarna sintetis pada makanan secara terus menerus akan mengakibatkan kerusakan organ hati.

Dampak negatif dari penggunaan pewarna sintetis dapat berkurang jika digantikan pewarna alami. Namun, pemakaian zat warna alami saat ini masih belum menjadi prioritas di lingkungan masyarakat karena proses untuk memperoleh zat warna tersebut lebih sukar dibandingkan zat warna sintetis (Mahayana, 2012). Untuk itu perlu diupayakan untuk mencari sumber pewarna alami dari bahan alam seperti pada tumbuhan. Salah satu hasil tanaman yang berpotensi menghasilkan pewarna alami adalah ubi banggai baku makulolong. Ubi banggai baku makulolong (Dioscorea bulbifera var celebica Burkill) berwarna merah keunguan dan diduga mengandung zat warna antosianin. Ashari (2010), melaporkan bahwa pigmen merah keunguan pada ubi banggai makulolong (Dioscorea bulbifera var celebica Burkill) merupakan senyawa antosianin yang dapat diekstrak dengan menggunakan etanol. Namun saat ini belum dimanfaatkan sepenuhnya oleh masyarakat selain hanya manjadi produk makanan untuk menggantikan beras.

Winarno (1995) dalam Neliyanti (2014) menjelaskan bahwa kestabilan zat warna yang bersumber dari tumbuhan dapat dipengaruhi beberapa kondisi, tergantung dari jenis zat warna tumbuhan tersebut. Penggunaan zat warna antosianin pada produk olahan pangan dipengaruhi oleh beberapa faktor, diantaranya stabilitas pewarna alami terhadap kondisi lingkungan seperti perubahan $\mathrm{pH}$, paparan sinar matahari dan lain-lain. Penggunaan antosianin sebagai pigmen atau pewarna makanan dan minuman seringkali dilakukan pada $\mathrm{pH}$ rendah, seperti untuk minuman beralkohol, minuman ringan, saos, manisan, yoghurt, makanan beku. Menurut Hidayah et al. (2014), zat warna alami kulit buah naga stabil pada $\mathrm{pH}$ 2-5 dan lama waktu pemanasan dapat menurunkan absorbansi zat warna. Merujuk dari hal-hal tersebut, maka pigmen ubi banggai sangat potensial dijadikan pewarna alami makanan yang ditinjau dari stabilitas $\mathrm{pH}$ dan paparan sinar matahari. 


\section{METODE PENELITIAN}

\section{Bahan dan Peralatan}

Bahan yang akan digunakan pada penelitian ini adalah ubi banggai; buffer klorida $\mathrm{pH} 2$; buffer sitrat $\mathrm{pH} \mathrm{3,} \mathrm{4,} 5$ dan 6; etanol 96\%; kertas saring; aluminium foil; dan akuades.

Peralatan yang digunakan pada penelitian ini adalah loyang, pisau/alat pemotang, gelas ukur (10, 100 dan 500 $\mathrm{ml}$ ), botol vial, seperangkat alat sentrifuse, pipet tetes, corong kaca, pipet volum $1 \mathrm{ml}$, rotari vakum evaporator, corong buchner, pompa vakum, labu ukur $25 \mathrm{ml}$, sendok zat, seperangkat alat spektrofotometer UVVis, $\mathrm{pH}$ meter, alat pengocok dan alat-alat gelas lainnya.

\section{Prosedur Penelitian}

\section{Preparasi Sampel}

Ubi banggai yang diperoleh dibersikan dari kulit terluarnya. Kemudian dicuci dengan air mengalir. Lalu bagian dalam dicacah dan siap untuk diekstraksi.

\section{Ekstraksi Ubi Banggai (Hidayah et al., 2014)}

Proses ekstraksi dilakukan dengan metode maserasi selama 24 jam. cacahan kulit ubi banggai ditimbang sebanyak $500 \mathrm{~g}$ lalu dimasukan ke dalam wadah kedap cahaya, selanjutnya ditambahkan 1000 ml etanol $96 \%$ dengan rasio perbandingan antara sampel dan pelarut sebesar 1:2 (b/v), lalu ditutup rapat. Setelah itu dikocok selama 1 jam setiap 6 jam menggunakan alat pengocok. Kemudian disaring menggunakan corong buchner dengan bantuan pompa vakum untuk memisahkan ekstrak dari residu. Ekstrak yang didapatkan kemudian dipisahkan dari pelarutnya dengan menggunakan rotari vakum evaporator. Setelah itu ekstrak pekat yang didapatkan disentrifuse dengan kecepatan 3000 rpm selama 30 menit.

\section{Penentuan Panjang Gelombang Maksimum}

Diambil $1 \mathrm{ml}$ ekstrak etanol ubi banggai dengan pipet volum $1 \mathrm{ml}$ lalu dimasukan ke dalam labu ukur $25 \mathrm{ml}$ kemudian ditambahkan akuades sampai tanda batas. Kemudian ditentukan panjang gelombang maksimum menggunakan spektrofotometer UV-Vis.

\section{Penentuan Absorbansi Awal}

Diambil $1 \mathrm{ml}$ ekstrak etanol ubi banggai dengan pipet volum $1 \mathrm{ml}$ lalu dimasukan ke dalam labu ukur $25 \mathrm{ml}$ kemudian ditambahkan akuades sampai tanda batas. Kemudian diukur absorbansinya menggunakan spektrofotometer UV-Vis. Perlakuan dilakukan sebanyak 3 kali.

Uji Stabilitas Ekstrak Ubi Banggai Terhadap Pengaruh pH Selama Masa Penyimpanan (Yudiono, 2011)

Diambil $1 \mathrm{ml}$ ekstrak ubi banggai dengan pipet volum $1 \mathrm{ml}$ lalu dimasukan ke dalam masing-masing 5 labu ukur $25 \mathrm{ml}$ lalu ditambahkan larutan penyangga yang telah disediakan pada masing-masing labu ukur secara berturut-turut yaitu penyangga $\mathrm{pH}$ 2, 3, 4, 5 dan 6 sampai tanda batas. Kemudian disiapkan wadah yaitu botol vial 
yang telah dibungkus dengan aluminium foil dan diberi label $\mathrm{pH} 2,3,4,5$ dan 6 . Kedalam masing-masing botol vial diisi dengan larutan dari labu ukur sesuai dengan $\mathrm{pH}$ masing-masing botol yang tersedia dan diletakan pada suhu ruang. Sampel disimpan selama masa penyimpanan 10 hari dan diukur absorbansinya pada panjang gelombang $550 \mathrm{~nm}$ setiap 24 jam sekali menggunakan spektrofotometer UV-Vis. Perlakuan dilakukan sebanyak dua kali. Lalu mengitung persen degradasi zat warna dengan menggunakan persamaan berikut

$$
\text { Degradasi }(\%)=\frac{\mathrm{Ao}-\mathrm{At}}{\mathrm{Ao}} \times 100 \%
$$

Dimana :

$A_{0}=$ absorbansi sebelum dilakukan pengujian

At $=$ absorbansi setelah dilakukan pengujian terhadap waktu

\section{Uji Stabilitas Ekstrak Ubi Banggai Terhadap Paparan Sinar Matahari Selama Masa Penyimpanan (Yudiono, 2011)}

Disediakan 5 botol vial gelap dan 5 botol vial bening. Masing-masing botol vial diisi dengan $1 \mathrm{ml}$ ekstrak ubi banggai. Kemudian masing-masing botol diletakan diluar ruangan agar terpapar sinar matahari. Paparan sinar matahari berlangsung selama 5 jam. Setiap 1 jam selama 5 jam diambil 1 botol vial bening dan botol vial gelap kemudian sampel yang berada didalam botol diencerkan dalam labu ukur $25 \mathrm{ml}$ dengan menambahkan akuades sampai tanda batas. Kemudian dilakukan pengukuran absorbansi dengan spektrofotometer UV-Vis. Perlakuan dilakukan sebanyak dua kali. Lalu menghitung persen degradasi zat warna dengan persamaan berikut:

$$
\text { Degradasi }(\%)=\frac{\mathrm{Ao}-\mathrm{At}}{\mathrm{Ao}} \times 100 \%
$$

Dimana :

$\mathrm{A}_{0}=$ absorbansi sebelum dilakukan pengujian

$A t=$ absorbansi setelah dilakukan pengujian terhadap waktu

\section{HASIL DAN PEMBAHASAN}

\section{Ekstrak Ubi Banggai}

Ekstrak pekat ubi banggai pada penelitian ini diperoleh dengan metode maserasi selama sehari semalam Ekstrak pekat yang diperoleh berwarna ungu sebanyak $150 \mathrm{ml}$. Pemilihan metode maserasi ini dikarenakan prosesnya sederhana dan dilakukan tanpa pemanasan, sehingga tidak merusak pigmen yang terkandung dalam ubi banggai. Menurut Achmad (1986), antosianin adalah senyawa yang berperan dalam memberikan warna merah, ungu dan biru pada beberapa bagian tumbuhan misalnya kelopak bunga dan buah.

Ekstrak ubi banggai ditentukan jenis senyawanya dengan menggunakan analisis kualitatif menggunakan spektrofotometer UV-Vis. Panjang gelombang maksimum ditentukan dengan mengukur sampel ekstrak ubi banggai pada rentang panjang gelombang 470-560 $\mathrm{nm}$. Hasil pengukuran didapatkan bahwa nilai absorbansi maksimum ekstrak ubi banggai yaitu $550 \mathrm{~nm}$. Hasil ini berada pada serapan senyawa antosianin yang 
terletak pada panjang gelombang 490-580 nm (Harborne, 1987).

Panjang gelombang $550 \mathrm{~nm}$ ini akan digunakan untuk menentukan absorbansi awal $\left(A_{0}\right)$ antosianin. Hasil yang diperoleh berdasarkan pengukuran dengan tiga kali pengulangan, yaitu 0,$522 ; 0,545$; dan 0,538 dengan rata-rata absorbansi awal $\left(A_{0}\right)$ adalah 0,535. Absorbansi awal akan digunakan selanjutnya pada penentuan degradasi pigmen ekstrak ubi banggai.

\section{Stabilitas Ekstrak Ubi Banggai Terhadap Pengaruh pH Selama Masa Penyimpanan}

Hasil uji stabilitas yang dilakukan selama masa penyimpanan 10 hari diketahui bahwa degradasi tertinggi pada pH 4 sebesar $83,73 \%$ dan terendah pada $\mathrm{pH} 2$ sebesar $37,38 \%$.

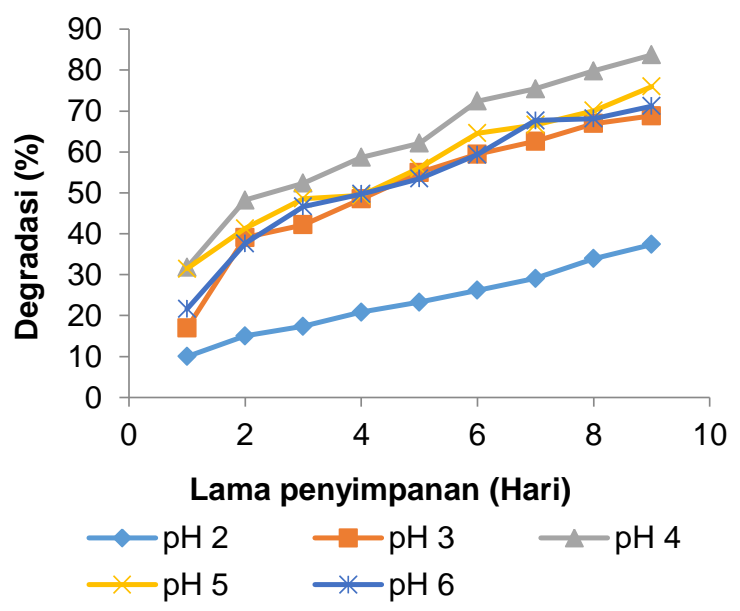

Gambar 1 Degradasi zat warna terhadap pengaruh $\mathrm{pH}$ selama masa penyimpanan

Masing-masing $\mathrm{pH} 2,3,4,5$, dan 6 mengalami degradasi pigmen yang berarti bahwa suasana asam yang berbeda mempengaruhi kestabilan zat warna ubi banggai, sedangkan pada $\mathrm{pH}$ yang lebih rendah $(\mathrm{pH} 2)$, pigmen antosianin cenderung stabil (Gambar 1). Hal ini membuktikan bahwa suasana asam yang berbeda berpengaruh terhadap kestabilan antosianin.

Kenaikan degradasi zat warna terhadap waktu penyimpanan selama 10 hari diketahui terjadi karna penurunan absorbansi yang berarti bahwa waktu penyimpanan masing-masing variasi $\mathrm{pH}$ dapat menurunkan kestabilan zat warna. Dalam perlakuan ini terlihat $\mathrm{pH} 3,4,5$, dan 6 mengalami degradasi yang lebih tinggi dibandingkan dengan $\mathrm{pH} 2$ yang mengalami degradasi namun tidak signifikan. Menurut Francis (1992) dalam Hidayah et al. (2014), pada kondisi pH yang rendah atau mendekati $\mathrm{pH} \mathrm{1,} \mathrm{warna}$ konsentrat akan semakin berwarna merah dan stabil.

Pada saat ekstrak ditambahkan larutan buffer terjadi perubahan warna dimana semakin tinggi nilai $\mathrm{pH}$ maka warna ekstrak semakin memudar.

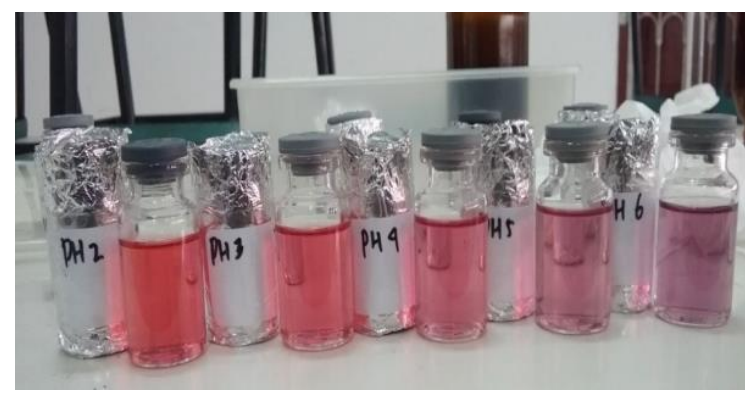

Gambar 2 Perubahan warna saat ekstrak ditambahkan buffer

Hasil ini sesuai dengan penelitian Mastuti et al. (2013), bahwa dalam hal warna, semakin tinggi nilai $\mathrm{pH}$ dalam suasana asam warna ekstrak akan 
menjadi pudar. Menurut Hidayah et al. (2014), peningkatan $\mathrm{pH}$ akan membuat warna antosianin memudar karena kation flavilium yang berwarna merah mengalami hidrasi menjadi karbinol yang tidak berwarna.

Rein (2005) dalam Neliyanti (2014) melaporkan bahwa pada $\mathrm{pH}$ rendah antosianin berbentuk kation flavilium merah, sedangkan pada saat $\mathrm{pH}$ dinaikkan $(>5)$, maka proton lebih cepat hilang sehingga terbentuk basa quinoidal berwarna biru atau ungu. Kenaikan $\mathrm{pH}$ juga dapat menyebabkan hidrasi kation flavilium sehingga terbentuk karbinol yang tidak berwarna.

\section{Stabilitas Ekstrak Ubi Banggai Terhadap Paparan Sinar Matahari Selama Masa Penyimpanan}

Hasil uji stabilitas terhadap paparan sinar matahari diketahui tingkat degradasi pada botol vial bening 41,96 \% dan pada botol vial gelap 36,91\%.

Setelah sampel dalam botol bening dan botol gelap dipaparkan terlihat bahwa setiap satu jam degradasi dari setiap botol vial meningkat (Gambar 3). Hal ini menunjukan bahwa sinar UV berpengaruh terhadap kestabilan zat warna sehingga semakin lama waktu penyinaran maka warna akan semakin memudar. Terlihat perbedaan degradasi antara sampel dalam botol vial bening dan juga sampel dalam botol vial gelap dimana sampel dalam botol vial bening memiliki tingkat degradasi yang lebih besar dibandingkan dengan sampel dalam botol vial gelap.

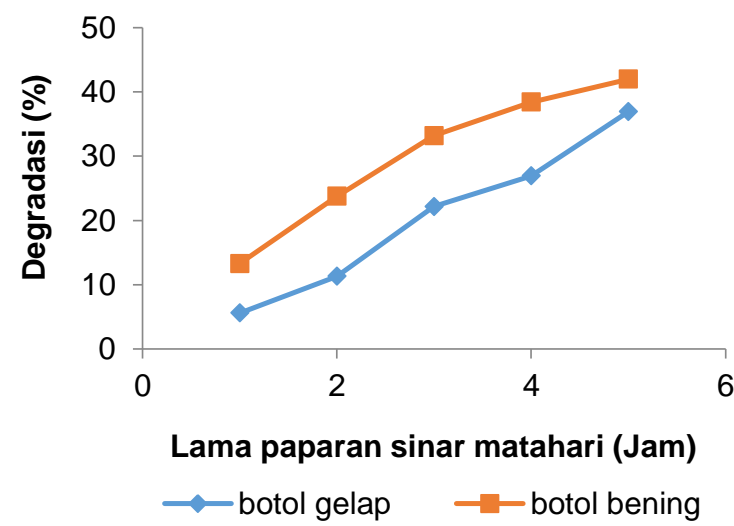

Gambar 3 Degradasi zat warna terhadap paparan sinar matahari selama masa penyimpanan

Lama paparan sinar matahari juga berpengaruh terhadap kestabilan ekstrak ubi banggai dimana semakin lama paparan sinar matahari maka tingkat degradasi juga semakin besar. Pada penelitian Hidayah et al. (2014) mengenai stabilitas sampel kulit buah naga terhadap lama paparan sinar matahari menunjukkan bahwa semakin lama waktu pemanasan maka nilai absorbansi semakin menurun dan zat warna memudar akibat kerusakan atau dekomposisi antosianin.

Menurut Markakis (1982), antosianin yang terdapat dalam zat warna merah dapat mengabsorbsi sinar UV. Energi radiasi sinar menyebabkan reaksi fitokimia pada spektrum tampak yang dapat merusak struktur antosianin sehingga mengakibatkan perubahan warna.

Menurut Wisnubroto (1983), matahari adalah sumber sinar utama untuk bumi dan atmosfer dengan energi berkisar 2,25 x $10^{27}$ joule/detik. Energi radiasi matahari atau insolasi terdiri atas sinar-sinar dengan panjang gelombang yang berbeda-beda. 
Sinar dengan panjang gelombang lebih pendek akan menghasilkan efek fotokimia tertentu dan mampu mempercepat proses oksidasi biomolekul. Jenie (1994) menyatakan bahwa waktu penyinaran dengan cahaya matahari 24 jam menyebabkan degradasi pigmen mencapai $56 \%$. Sinar matahari mengandung gelombang ultraviolet yang memiliki energi yang besar, sehingga saat meradiasi senyawa fiotkimia akan menyebabkan terbentuknya radikal bebas yang berujung pada pigmen menjadi tidak stabil. Menurut Effendi (1991) dalam Wulaningrum (2013), kesetimbangan diantara struktur-struktur antosianin sangat dipengaruhi oleh cahaya.

\section{KESIMPULAN}

Setelah masa penyimpanan selama 10 hari ekstrak ubi banggai mengalami degradasi pada masing-masing variasi $\mathrm{pH}$ 2, 3, 4, 5, dan 6 sehingga stabilitas zat warna menurun. Penurunan tertinggi pada pH 4 sebesar $83,73 \%$ dan terendah pada pH 2 sebesar 37,38\%.

Setelah terpapar sinar matahari selama 5 jam ekstrak ubi banggai mengalami degradasi baik pada botol vial bening maupun pada botol vial gelap sehingga stabilitas zat warna menurun. Penurunan tertinggi pada botol vial bening sebesar 41,96 \% dibandingkan dengan botol vial gelap sebesar $36,91 \%$.

\section{DAFTAR PUSTAKA}

Achmad, S, A. 1986. Buku Materi Pokok Kimia Organik Bahan Alam. Jakarta: Karunika.

Ashari, 2010. Ekstraksi Dan Karakterisasi Antosianin Dari Ubi Banggai Baku Makulolong (Dioscorea bulbifera var celebica Burkill). Skripsi. Palu: Fakultas Matematika Dan IImu Pengetahuan Alam Universitas Tadulako

Depkes RI, 2012. Parameter Standar Umum Ekstrak Tumbuhan Obat. Jakarta: Departemen Kesehatan Republik Indonesia.

Harborne, J, B. 1987. Metode Fitokimia. Penuntun Cara Modern Menganalisis Tumbuhan. Alih bahasa Kosasih Padmawinata. Bandung: Institut Tehnologi Bandung.

Hidayah, T., Pratjojo, W., Widiarti, N. 2014. Uji Stabilitas Pigmen dan Antioksidan Ekstrak Zat Warna Alami Kulit Buah Naga. Indonesian Journal of Chemical Science. 3 (2): 135-140.

Jenie, B.S.L., Helianti, dan S. Fardiaz. 1994. Pemanfaatan Ampas Tahu, Onggok, dan Dedak untuk Produksi Pigmen Merah oleh Monascus purpureus. Buletin Tekhnologi dan Industri Pangan. (5):22-29

Kumalaningsih, S. 2006. Antioksidan Alami. Surabaya: Trubus Agrisarana.

Mahayana, A. 2012. Pengaruh Pelarut dan Waktu Ekstraksi pada Isolasi Zat Warna dari Daun Jati. Surakarta. J. Teknol. dan Industri Pangan. 25 - (2) 2014 
Markakis, P. 1982. Anthocyanin as Food Colors. New York: Academic Press.

Mastuti, E., Fristianingrum, G., Andika, Y. 2013. Ekstraksi Dan Uji Kestabilan Warna Pigmen Antosianin Dari Bunga Telang (Clitoria ternatea L.) Sebagai Bahan Pewarna Makanan. Simposium Nasional RAPI XII - 2013 FT UMS, hIm. 44-51.

Neliyanti. 2014. Ekstraksi Dan Uji Stabilitas Zat Warna Alami Dari Buah Lakum (Cayratia trifolia (L.) Domin). JKK. 3 (2): 30-37

Wisnubroto, S., Aminah, S.L., dan Nitisapto, M. 1983. Asas-asas Meteorologi Pertanian. Jakarta: Ghalia Indonesia.

Wulaningrum, R, A. 2013. Pengaruh Asam Organik Dalam Ekstraksi Zat Warna Kulit Buah Manggis (Garcinia mangostana). Indonesian Journal of Chemical Science. 2 (2): 2252-6951

Yudiono, K. 2011. Ekstraksi Antosianin Dari Ubi jalar Ungu (Ipomoea batatas Cv. Ayamurasaki) Dengan Teknik Ekstraksi Subcritical Water. Jurnal Teknologi Pangan. 2 (1): 1-30 